\title{
THE EFFECT OF PERCEPTIONS OF ORGANIZATIONAL SUPPORT ON DECISION MAKING DURING THE COVID-19 PANDEMIC
}

\author{
Author \\ Darisma Eka Saputri ${ }^{1}$, Awang Setiawan Wicaksono ${ }^{2}$, Ima Fitri Sholichah ${ }^{3}$ \\ Psychology Faculty, Universitas Muhammadiyah Gresik \\ darismaekasaputri@gmail.com ${ }^{1}$,awangwicaksono.psi@umg.ac.id ${ }^{2}$, ima_fitri@umg.ac.id ${ }^{3}$
}

\begin{abstract}
This study aims to determine whether the perception of organizational support has an effect on decision making during the Covid-19 pandemic. This study uses a quantitative approach. The sample technique used is the saturated sample technique. The method of collecting data from the two variables used a questionnaire arranged in the form of a Likert scale. Analysis of research data using simple non-linear regression techniques. The results showed that for the $\mathrm{R}_{\text {(square) }}$ value of 0.234 or $23.4 \%$ of the perception of organizational support to influence decision making. Meanwhile, $76.6 \%$ is influenced by other factors which are not examined. Based on data analysis, it can be concluded that there is an effect of perceived organizational support on organizational support on decision making during the Covid-19 pandemic.
\end{abstract}

\section{Keywords: Decision Making, Perceptions of Organizational Support.}

\section{INTRODUCTION}

Human Resources (HR) in an industry or organization plays an important role in making good and appropriate policies. Recently, the Covid-19 pandemic has become a serious problem for almost all countries in the world, including Indonesia. The Covid-19 pandemic is a disease or outbreak that can be transmitted caused by a newly discovered type of Corona virus, this new virus was previously unknown before the outbreak in Wuhan, China, in December 2019 (World Health Organization).

Disaster is something that cannot be predicted, according to Law no. 24 of 2007, a disaster is an event or occurrence that can threaten, disrupt people's lives and livelihoods caused, whether it is caused by natural factors or non-natural factors, human factors that can cause casualties, such as: humans, environmental damage, property losses and psychological impact.

Data from the Chamber of Commerce and Industry (Kadin) on May $3^{\text {th }} 2020$, stated that 1,657 hotels closed employees who were laid off and laid off from the textile sector reaching 2.1 million people, the shoe/footwear sector 500 thousand people, retail 400 thousand people, and land transportation of 1.4 million people. This is also felt by state-owned companies, SOE Minister Erick Thohir said in a virtual presentation, "90\%. BUMN Companies Affected by Pandemic Almost all business sectors cannot be separated from the negative impact of the development of this virus. Although not all of them experience this condition. The current condition is that $90 \%$ of companies are affected. SOEs with less impact are Telkom, health and palm oil. Other impacts are there. Wednesday $\left(20^{\text {th }}\right.$ May 2020). 
Related to this condition, companies that have many divisions, products, markets, and technologies tend to be more formal in implementing the tactical decision-making process. Tactical decision making depends on the decision-making model used by company leaders at the tactical level. According to Mintzberg and Theoret (1976), the process of decision making is divided into 3 phases, namely, identification, development, and selection. Each phase is related and forms a process called the general decision-making model.

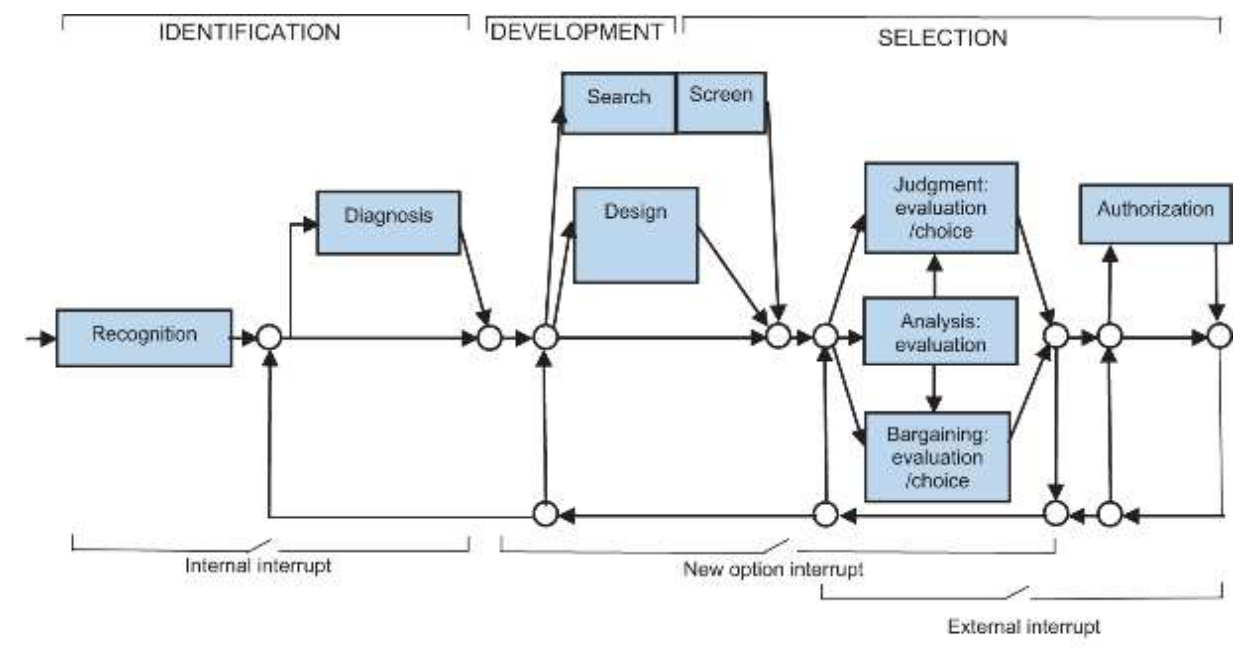

Source: Mintzberg et al. (1976, p. 266)

Figure 1. General Model of Decision-Making Process

Eisenberger (in Tanudjaja, 2013) explains that perceptions of organizational support have an impact, such as: job related affect, organizational commitment, withdrawal behavior, employee involvement and the desire to leave the organization and are able to reduce the tension experienced by workers. Based on organizational support theory, a high perception of organizational support can improve work attitudes and produce effective and efficient work behavior. Work attitudes and work behaviors that are effective and efficient are a form of social exchange that occurs between employees and the organization. When employees feel that the organization provides support to them, then they will also try to pay back for the benefit of the organization. Miao (in Jin and Zhang, 2014).

The results of this study are in line with (Fatimah, Rosliana and Sulistianti, 2019) which states that there is no significant relationship between lifestyle and self-concept on consumer decision making in choosing a coffee shop. So, the suggestion for further researchers is to be able to examine other variables that can have a significant effect on decision making. $99.95 \%$ of decision making is influenced by other factors not examined in this study including psychological factors, such as: learning and memory besides that there are also social factors, motivation, perception, culture and one's personality.

Meanwhile, in this study, researchers wanted to see whether the perception of organizational support had an effect on tactical decision making during the Covid-19 pandemic. Researchers have an interest in this theme because researchers are interested in whether there is a situation that occurs in the current Covid-19 Pandemic, especially in terms of the perception of organizational support having an influence on making a decision to make the right policy in a company. 


\section{METHODS}

\section{Data source and sampling}

The subjects of this research are 43 employes human resources at Holding and subsidiary, with the following criteria:

a. Employees of Holding and subsidiary.

b. Working in the Human Resources Department.

c. The current position is at least Supervisor and maximum is Manager.

In this study using a sampling technique, namely non-probability sampling with the type of sampling technique used, namely saturated sampling because not all populations have criteria that match the phenomenon under study.

Measure

The technique used in this research is a questionnaire. Researchers used a Likert scale so that the data obtained were real. The data obtained from the questionnaire is a scale used to measure attitudes, opinions and perceptions of organizational support for a person or group of people for social phenomena (Sugiyono, 2016: 93).

The Likert scale can show the measured variables by describing the variables into indicator variables. Then the indicator is used as a statement item (Sugiyono, 2016: 93). The alternative forms of answers provided in the questionnaire are:

a. Strongly Agree

B. Agree

C. Quite Agree

D. Disagree

e. Strongly Disagree

The researcher uses the Decision-Making Everyday Life instrument compiled by Mincemoyer and Perkins (2003) which is a measuring tool compiled by Mincemoyer and Perkins (2003). Decision Making Everyday Life a measuring tool for decision making consisting of 20 items. The Survey of Perceived Organizational Support (SPOS) instrument is a measuring instrument compiled by Eisenberger, Huntington, Hutchinson and Sowa (1986). Survey of Perceived Organizational Support (SPOS) is a tool to measure the perception of organizational support which consists of 36 items.

\section{RESULT}

To see the effect between variables, non-parametric statistical approaches were used and non-linear regression data analysis techniques were used. Researchers tested non-linear regression using SPSS 2.5. for windows.

The hypotheses proposed are as follows:

Ho: There is no effect of perceived organizational support on tactical decision making during the Covid-19 pandemic.

Ha: There is an influence of the perception of organizational support on tactical decision making during the Covid-19 pandemic.

The results of the regression test, the $\mathrm{R}$ square value is 0.366 , in other words $36.6 \%$ of the organizational support that influences decision making. While $32.6 \%$ is influenced by other factors that are not examined.

The results of the $\mathrm{F}$ test analysis obtained an $\mathrm{F}$ value of 25.413 for degrees of freedom $\mathrm{k}=1$ and nkl=46-1-1=44 with a significant level of 0.000 , because the significant value of 0.000 is less than 0.05 , the regression model can be used to predict the perceived support variable. organizations influence decision-making. 
The results of the Regression Coefficient Test show that the decision-making variable is 16.945 while the perceived value of organizational support is 0.224 . These results show the regression line between the perceived organizational support variable and decision making.

\section{DISCUSSION}

This study was conducted to test whether there is an influence on the perception of organizational support on tactical decision making during the Covid-19 pandemic at a big company. Based on the exposure of the research results and the results of the analysis using nonlinear regression, the research hypothesis states that there is an effect of perceived organizational support on decision making with a significant value of 0.00 less than 0.05 . This is in line with research conducted by Puspaatmaja and Satrya (2016: 535) which shows that job satisfaction and affective commitment obtained by employees at work will be achieved by involving employees in participating in decision making, as well as support from the organization. Thus, the perception of organizational support is able to fully mediate between employee participation in decision making and employee job satisfaction. By using the path analysis method by showing a value of 4.80 which is greater than 1.96 so that the perceived influence of organizational support is able to fully mediate between employee participation in decision making and employee job satisfaction.

Regression test results show that the regression coefficient R-square or coefficient of determination (Rsquare) is 0.366 or $36.6 \%$. This shows that the variable perception of organizational support affects decision making by $36.6 \%$, meaning that the regression coefficient is positive, so it can be said that the higher the perception of organizational support, the higher the decision making is made. While the remaining $63.4 \%$ is influenced by other factors not examined.

Other factors that have not been studied by $63.4 \%$ may be influenced by other psychological factors according to (Kotler, 2003) which include motivation, knowledge, beliefs and convictions. This is in line with research by (Fatimah, Rosliana and Sulistianti, 2019) which states that there is no significant relationship between lifestyle and self-concept on consumer decision making in choosing a coffee shop.

Decision-making variables that are mostly chosen by employee respondents are item number 1 with a percentage of $93.5 \%$, item number 2 with a percentage of $91.3 \%$, and item number 6 with a percentage of $83.9 \%$. This shows that most of the employees of the Human Resources Department show that some of the employees of the Human Resources Department have a high level of decision making because they have been able to look for possibilities in every problem, are able to think about a situation and are able to observe and interpret the results. This is in accordance with what is defined by Eisenfuhr (2011) decision making is the process of making a choice from a number of alternatives to achieve the desired result. This definition has three key elements. First, decision making involves making a choice from a number of options. Second, decision making is a process that involves more than just a final choice from among alternatives. Third, the "desired outcome" mentioned in the definition involves the goal or target resulting from the mental activity that the decision maker is involved in obtaining the final decision. (Eisenfuhr: 2011) 
The variable perception of organizational support that was chosen by the respondents was item number 6 with a percentage of $84.8 \%$, item number 14 with a percentage of $91.3 \%$, and item number 36 with a percentage of $84.6 \%$. This shows that most employees of the Human Resources Department indicate that some employees of the Human Resources Department have a high perception of organizational support because the organization is fair in providing opportunities for employees and superiors are able to make employees a sign of organizational support. This is in accordance with what is defined by Miao (in Jin and Zhang, 2014) that a high perception of organizational support can improve work attitudes and produce effective and efficient work behavior. Work attitudes and work behaviors that are effective and efficient are a form of social exchange that occurs between employees and the organization. When employees feel that the organization provides support to them, then they will also try to pay back for the benefit of the organization.

\section{CONCLUSION}

Based on the results of research and data analysis using simple non-linear regression techniques that have been carried out in this study, it can be concluded that Ho is rejected and Ha is accepted, which means that there is an influence of the independent variable, namely the perception of organizational support for tactical decision making during the Covid-19 pandemic.

\section{REFERENCES}

Abdul, R. S. (2009). Psikologi Suatu Pengantar. Jakarta : Kencana.

Arifin, \& Zainal. (2008). Metodelogi Penelitian Pendidikan. Surabaya: Lentera Cendikia.

Arikunto, S. (2010). Prosedur Penelitian Suatu Pendekatan Praktik. Jakarta : Rineka Cipta.

Azwar. (2012). Metode Penelitian. Yogyakarta: Pustaka Pelajar.

Azwar, \& Saifuddin. (2014). Metode Penelitian. Yogyakarta: Pustaka Pelajar.

Chaplin, J. (2006). Kamus Lengkap Psikologi. Jakarta: PT. Raja Grafindo Persada.

Cnbc Indonesia. https://www.cnbcindonesia.com/market/20200522080922-17-160162/phkancam-industri-properti-90-bumn-terdampak-covid-19

Creswell, \& Jhon, W. (2014). Research design pendekatan kualitatif, kuantitaf, dan mixed. Yogyakarta: Pustaka Pelajar.

Darmawan. (2014). Metode Penelitian Kuantitatif. Cetakan Kedua. Bandung: PT. Remaja Rosdakarya.

Delfira. (2015). Presepsi Pegawai Tentang Pengambilan Keputusan Oleh Atasan Langsung di Kantor Koordinator Perguruan Tinngi Swasta Wilayah X (Sumatera Barat, Riau, Jambi,Kepulauan Riau). Jurnal Administrasi Pendidikan .

Drummond, H. (1995). Pengambilan Keputusan yang Efektif. Jakarta: PT. Gramedia.

Eisenberger, Fasolo, P., \& LaMastro, V. (1990). Perceived organizational support and employee diligence, commitment, and innovation. Journal of Applied Psychology, 51-59.

Eisenberger, R., Stinglhamber, F., Vandenberghe, C., Sucharski, L., \& Rhoades, L. (2002). Perceived supervisor support: Contributions to perceived organizational support and employee retention. Journal of Applied Psychology, 565-573.

Fatimah, S., Rosliana, L., \& Sulistiani, N. W. (2019). Pengaruh Gaya Hidup Dan Konsep Diri Terhadap Pengambilan Keputusan Konsumen Dalam Memilih Kedai kopi Di Samarinda.

Feldman, \& Robert, S. (1999). Psychology. Boston-USA: McGraww-Hill Book Co. 
Harren, V. (1979). A Model of Career Decision - Making for College Students. Journal of Vocational Behavior, Vol 14, 119-133.

Jin, Y., \& Zhong, Y. (2014). Contextual Factors Affecting The Influence of Perceived. Guangdong University of Technology.

Kasiram. (2008). Metodologi Penelitian. Malang: UIN-Malang Pers.

Koontz, H., \& Cryil, O. (2005). Principle of Management : Analysis if manajerial fuction. Tokyo: Mc Graw Hill, Kogakusha Ltd.

Lunenburg. (2010). School Fasilities Management. National Forum Of Educational Administration \& Supervision Journal, 1-7.

Mar'at. (1991). Sikap Manusia Perrubahan Serta Pengukurannya. Jakarta: Ghalia Indonesia.

Mintzberg, H. (1979). The Structuring Of Organization. USA: Eaglewood.

Morgan, C. (1987). Psikologi Sebuah Pengantar. Jakarta: Pradnya Paramita.

Muchtar, T. (2007). Studi Komparatif Persepsi (Skripsi). Pendidikan Teknik Sipil. Bandung.

Prabowo, W., Yusuf, M., \& Setyowati, R. (2019). Pengambilan Keputusan Menentukan Jurusan Kuliah Ditinjau Dari Student Self Efficacy Dan Persepsi Terhadap Harapan Orang Tua. Jurnal Kajian Psikologi Pendidikan dan Bimbingan Konseling , 42-48.

Purwanto, N. (2006). Psikologi Pendidikan . Bandung: PT Remaja Rosdakarya.

Rakhmat, \& Jalaluddin. (1996). Psikologi Kominitas. Bandung: Remaja Rosdakarya.

Ranyard, R., Crozier, W. R., \& Svenson, O. (1997). Decision Making Cognitive Models and Explanations. ISBN 0-203-75263.

Sarwono, S. (2002). Psikologi Sosial : Individu dan Teori-teori Psikologi Sosial. Jakarta: Balai Pustaka.

Sharf, R. (1992). Appling Career Develompment Theory to Counseling . California: Pasific Grove.

Sobur. (2003). Psikologi Umum . Bandung: Pustaka Setia.

Sternberg, R. (2008). Psikologi Kognitif. Yogyakarta: Pustaka Pelajar.

Sugiyono. (2016). Metode Penelitian Kuantitatif, Kualitatif dan R\&D. Bandung: PT. Alfabet.

Syamsi, I. (2000). Pengambilan Keputusan dan Sistem Informasi. Jakarta: Sinar Grafika Offset.

Tanudjaja, R. M. (2013). Hubungan Antara Konflik Keluarga-Kerja, Makna Kerja Sebagai Panggilan, dan Persepsi Dukungan Organisasional dengan. Jurnal Ilmiah Universitas.

Undang-undang Republik Indonesia No. 24 tahun 2007 tentang Penanggulangan Bencana

Walgito. (1990). Psikologi Sosial. Yogyakarta: Andi Yogyakarta.

Walgito. (2003). Psikologi Sosial. Yogyakarta: Andi Yogyakarta.

Walker, J. W. (1980). Human Resource Planning. USA: Mc Graw-Hill Inc.

Wang, \& Ruhe. (2007). The Cognitive Process of Decision Making. International Journal of Cognitive Informatics and Natural Intelligence, 73-85.

Wang, Y., \& Ruhe, G. (2007). Cognitive Process of Decision Making. International Journal of Cognitive Informatics and Natural Intelligence.

Winarsunu. (2015). Statistik dalam penelitian psikologi \& pendidikan. Malang: Universitas Muhammadiyah Malang. 